\title{
Pollen analysis of animal coprolites recovered from vegetation mounds in El-Ga'ab paleolake: evidence for vegetation history of the desert of northern Sudan
}

\author{
Mohammed Nasreldein ${ }^{1}$, Ikram Madani Ahmed ${ }^{2} *$ and Yahia Fadl Tahir ${ }^{3}$ \\ ${ }^{1}$ Department of Archaeology, Faculty of Arts and Human Sciences, University of Gezira, Sudan \\ ${ }^{2}$ Department of Botany, Faculty of Sciences, University of Khartoum, Sudan \\ ${ }^{3}$ Department of Archaeology, Faculty of Arts, University of Khartoum, Sudan \\ *Corresponding Author: Ikramahmed3@yahoo.com
}

\begin{abstract}
In arid zones vegetation mounds are natural indicators for land degradation. Studying plants and animals remains in different strata of these mounds provide information about the past land use in which parts of the natural environment were modified into arable fields and pastures. They are suitable sites for preserving animal coprolites. In this study, two samples of different animal coprolites were collected from vertical trenches in vegetation mounds of Um Hilal and El-Hamra areas of El-Ga'ab depression in northern Sudan. Pollen grain analysis was conducted and eleven species that belong to eight families were identified. Five species recorded for El Hamra area and nine species were identified for Um Hilal area. Most of the pollen grains were identified as Suaeda monoica and Salsola imbricata which are halophytes indicates habitats of high soil salinity in El-Ga'ab depression. These species are still dominant in other law elevated areas of less dry sand dunes. Polygonum sp. Pollens were recorded in Um Hilal area indicating a moist habitat. Record of the comparatively large number of tree pollen grain of Acacia ehrenbergiana indicates no change in the dominant tree species. Presence of the pollen grains of Triticum sp. (wheat) and Heliotropium parciflorum is an evidence for past agricultural activities. This study recommended further intensive investigations of the old dry vegetation mounds distributed in the desert of northern Sudan to reconstruct its palaeoenvironment.
\end{abstract}

Keywords: Archaeobotany, Pollen grains, Coprolite, Northern Sudan, Vegetation history.

\section{INTRODUCTION}

Many researchers have suggested that the deserted areas had faced a great transformation concerning the vegetation cover due to the aridity factors, as a result of that transformation the tropical plant communities had replaced by herbaceous-dominated dessert ecosystems; which was proven by pollen taxa from archaeological sites (Mercuri et al., 2011; Lezine et al., 2011; Florenzano et al., 2016). Tropical plant taxa such as Celtis-type, Alchornea, Syzygium-type and Piliostigma which were discovered as a pollen grains in the Sahelian and Saharan climates, started to appears around 8500 BC (Watrin et al., 2009). Meanwhile, some Sahelian plant species such as Acacia had begun to appear in the Saharan regions around 6300-5800 BC (Mercuri, 2008; Watrin et al., 2009).

In Sudan, Lopez Saez \& Garcia (2003) studied some pollen samples, which were collected from three prehistoric sites along the Blue Nile, el- Mahalab and Sheikh Mustafa, and Sheikh el-Amin. These three archaeological sites were dated to the Early Holocene and to the Middle Holocene, and they are situated within the present semi-arid zone in Sudan. According to the identified pollen grains; such as Acacia and Herbaceous sp. (Gramineae) it has noted that the area was open Savannah grassland. These pollen results are very similar to the pollen grains results from the Neolithic site of Kadero (Barakat, 1995). Florenzano et al. (2016) presented fragmentary records of pollen and non-pollen palynomorphs from archaeological sites in Northern Upper Nubia, particularly from Sai Island. Their study concluded that the dry environments and deserts could not provide a good state of preservation for pollens as the wet environments. A recent study by Florenzano et al. (2018) has shown some botanical results based on pollen analysis from Holocene archaeological sites on Sai Island in Northern Sudan. Their results provided a valuable contribution to the understanding of past human-environment interactions and land transformations in the region. This paper aims to report on the results of pollen analysis of animal coprolites obtained from two vegetation mounds (Tarabeel) in ElGa'ab Depression; particularly from Um Hilal and El Hamra areas in the desert of northern Sudan.

\section{MATERIALS AND METHODS}

\section{Study area}

The study area is located in El-Ga'ab palaeolake which is situated on the western bank of the Nile River south of the 
Third Cataract figure 1. The total area of the palaeolake is about $700 \mathrm{~km}^{2}$ extends for $123 \mathrm{~km}$ across the Western desert. It was connected to the Nile during the early Holocene and separated but remains flooded by the Nile during the MidHolocene (Tahir, 2012). According to Madani et al. (2015) the larger part of the area is an absolute desert with an average annual precipitation less than $0.1 \mathrm{~mm}$. Wickens (1982) considered this area as part of the most arid areas of the world. Madani et al. (2015) documented the presence of old vegetation mounds formed mainly by Tamarix aphylla (L.) Karst. near the old settlement relics, such as graves, churches and other buildings assigned to the Christian period. Materials collection sites inside El-Ga'ab are located in Um Hilal, and El-Hamra areas, about $33 \mathrm{~km}$ and $36 \mathrm{~km}$ from the Nile respectively.

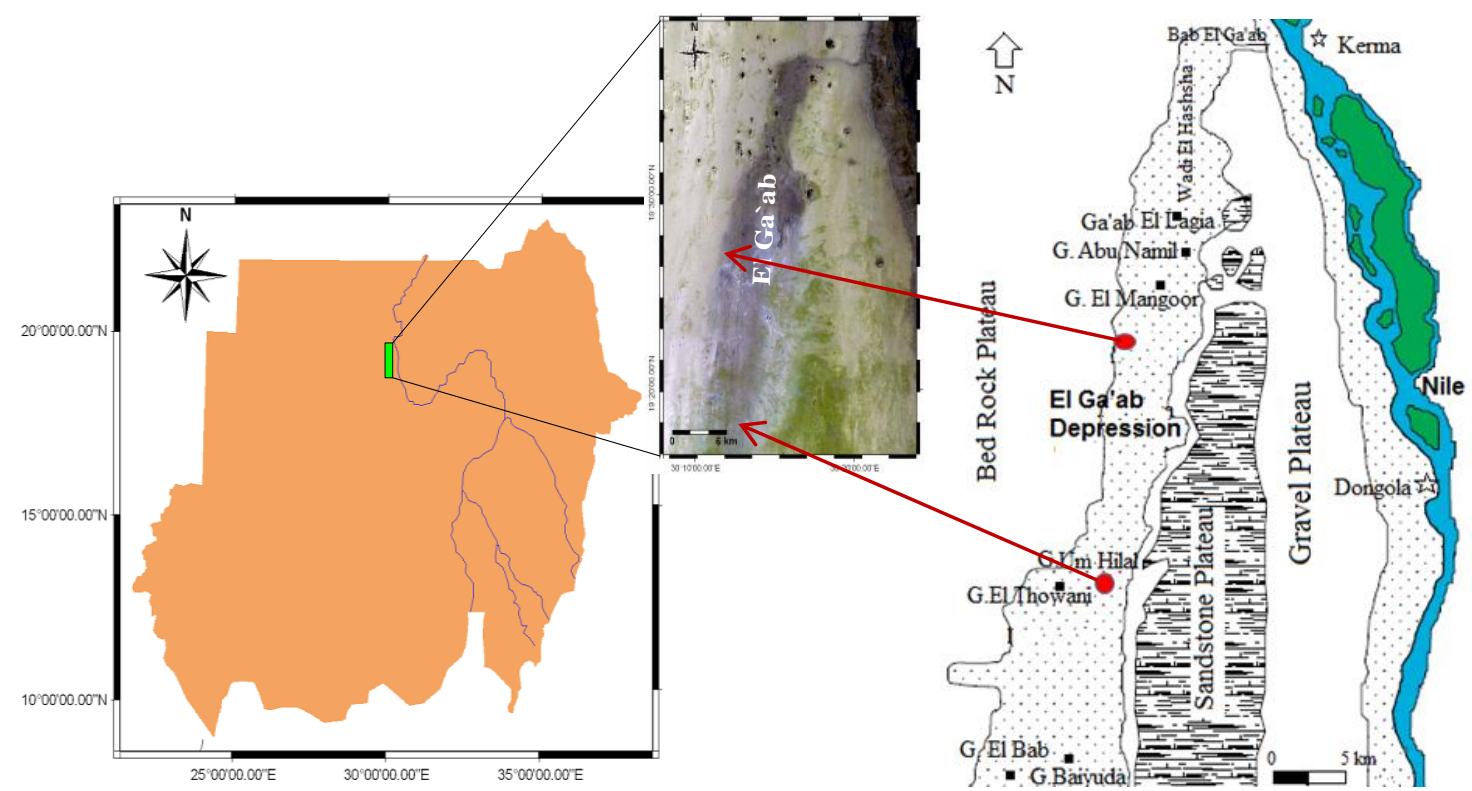

Figure 1. Location map of the samples collection sites in El-Ga'ab area. [adopted and modified from Babiker (2017)]

\section{Collection and analysis of animal coprolites}

Two samples of different animal coprolites were collected from vertical trenches in vegetation mounds of Um Hilal and El-Hamra areas during in 2015 (Figs. 2 \& 3). Samples were treated for pollen analysis following the standard acetolysis method (Erdtman, 1934, 1960; Faegri \& Iversen, 1975). Standard taxonomic features such as general shape class, shape from different views, Apertures, exine feature, were used for the identification of pollen grains under the light microscope (A. KRÜSS. OPTRONIC GERMANY D-22297) with the help of magnification powers: 1000x and 400x. Different views of pollens were photographed under the microscope using digital camera and light microscope at the laboratories of Faculty of Science, Department of Botany, University of Khartoum. Authentication of the identification was done consulting relevant atlases, publications and electronic photographic galleries (El Ghazali, 1993; Gosling et al., 2003; Azzazy 2011; online global pollen project accessed at https://globalpollenproject.org/Taxon?rank=Species and online photographic gallery of pollen grains accessed at https://pollenatlas.net/). Results were documented for the identified species and their corresponding families. Updating of plant names was taken into account according to the recent literature of the world plant list http://www.theplantlist.org/). The number of pollen grains identified for species was counted for each location.
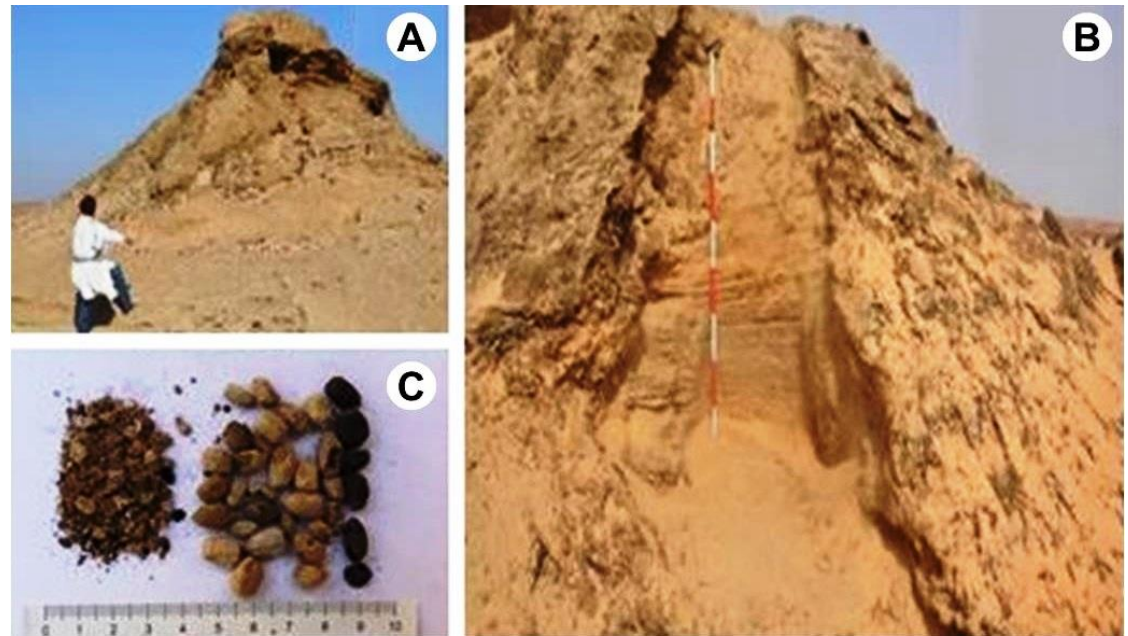

Figure 2. Coprolites samples from Um Hilal area: A, Vegetation mound; B, Vertical trench on the vegetation mound; $\mathbf{C}$, Animal coprolites. 

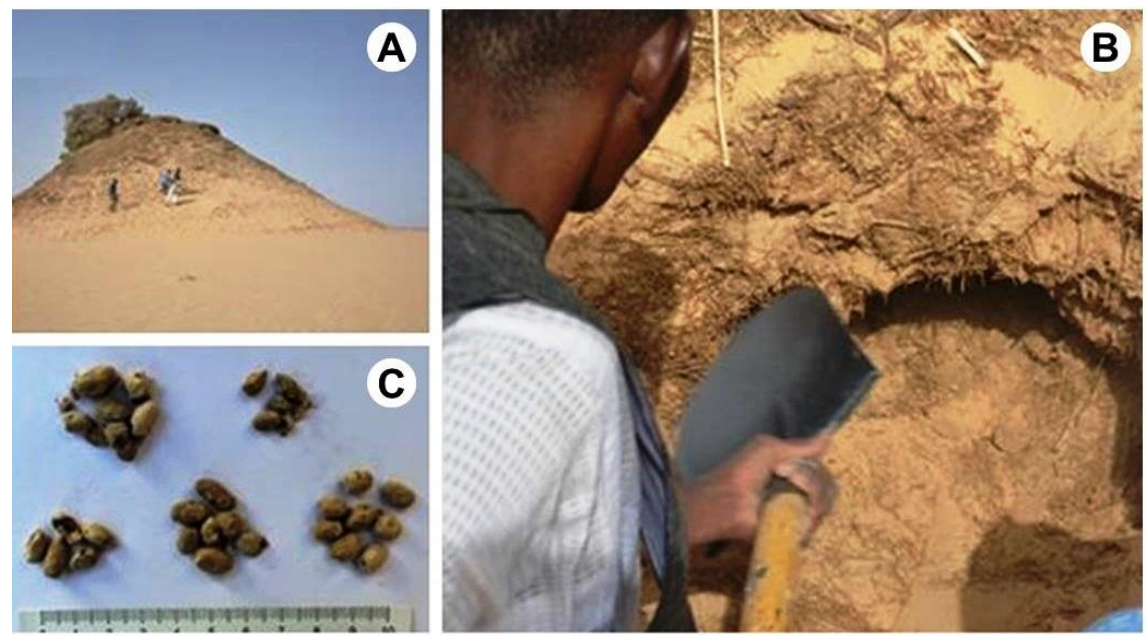

Figure 3. Coprolites samples from El-Hamra area: A, Vegetation mound; B, Trench on the vegetation mound; C, Animal coprolites.

\section{RESULTS}

In this study eleven species that belong to eight families have been identified from the pollen grains samples. Five species were recorded for El Hamra area and nine species were identified for Um Hilal area. Figures 4 and 5 Shows pollen grains under magnification power x1000 from Um Hilal area and al Hamra respectively. Table 1 shows the identified plants from Um Hilal and El Hamra areas with their corresponding density recorded for the studied samples. Pollen sample from Um Hilal shows the highest density record for Suaeda monoica Forssk. ex J.F.Gmel. followed by Salsola imbricata Forssk. which is also reported to be of the highest records in El Hamra pollen sample. Figures 6 and 7 shows the proportions of different plant species identified form pollen samples of Um Hilal and El-Hamra.
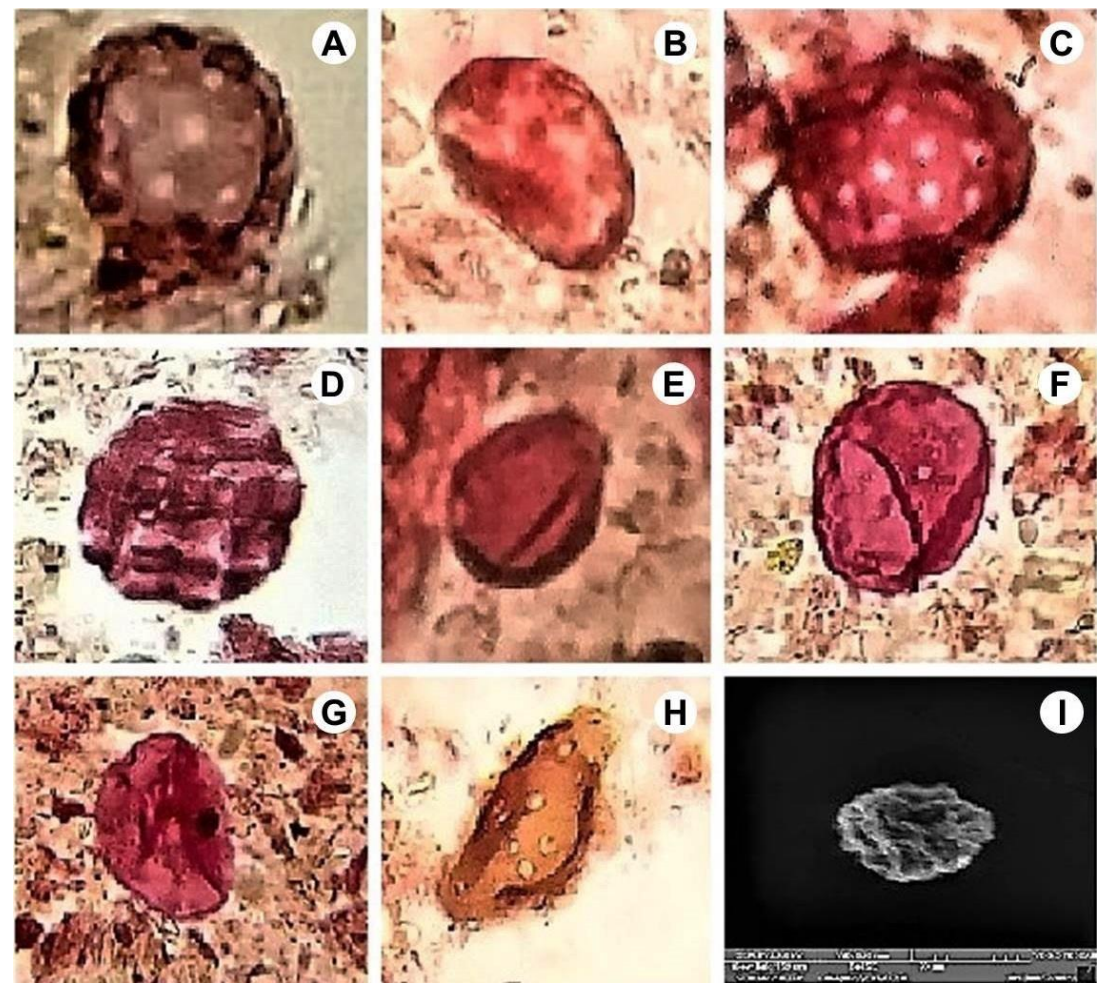

Figure 4. Pollen grains from Um Hilal area: A, Salsola imbricata Forssk.; B, Phoenix dactylifera L.; C, Suaeda monoica Forssk. ex J.F. Gmel.; D, Acacia ehrenbergiana Hayne; E, Heliotropium parciflorum (Mart.) Gürke; F, Triticum sp.; G, Cassia sp.; H, Hyphaene thebaica (L.) Mart; I, Polygonum sp.

Table 1. Identified species and their corresponding density in pollen samples.

\begin{tabular}{llrr}
\hline & Identified Plants species & \multicolumn{2}{c}{ Numbers of specimens } \\
\hline Family name & Species name & Um Hilal & El Hamra \\
\hline Amaranthaceae & Salsola imbricata Forssk. & 13 & 8 \\
Arecaceae & Phoenix dactylifera L. & 3 & 5 \\
Amaranthaceae & Suaeda monoica Forssk. ex J.F. Gmel. & 20 & - \\
Leguminosae & Acacia ehrenbergiana Hayne & 5 & - \\
Boraginaceae & Heliotropium parciflorum (Mart.) Gürke & 7 & - \\
\hline
\end{tabular}




\begin{tabular}{llcc}
\hline Poaceae & Triticum sp. & 6 & - \\
Leguminosae & Cassia sp. & 5 & 4 \\
Arecaceae & Hyphaene thebaica (L.) Mart & 2 & - \\
Tamaricaceae & Tamarix aphylla (L.) H.Karst & - & 6 \\
Cappariaceae & Capparis sp. & - & 3 \\
Polygonaceae & Polygonum sp. & 1 & - \\
\hline
\end{tabular}
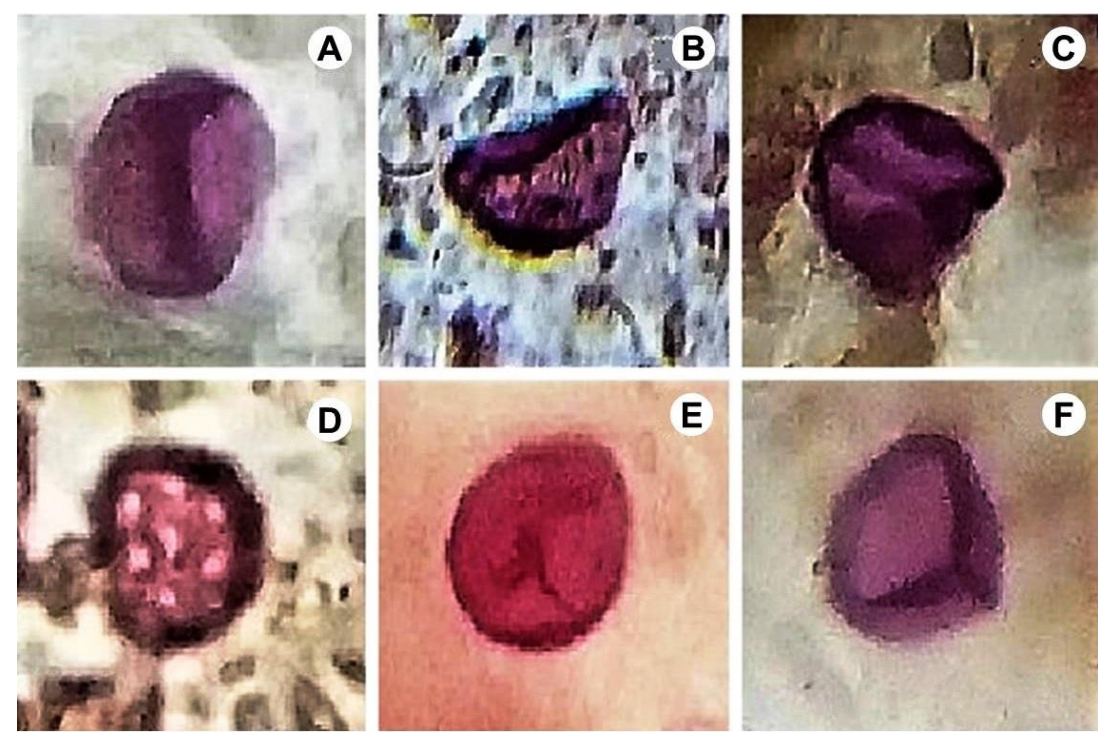

Figure 5. Pollen grains from El Hamra area: A, Tamarix aphylla (L.) H.Karst; B \& C, Phoenix dactylifera L.; D, Salsola imbricata Forssk. ex J.F. Gmel.; E, Cassia sp.; F, Capparis sp.

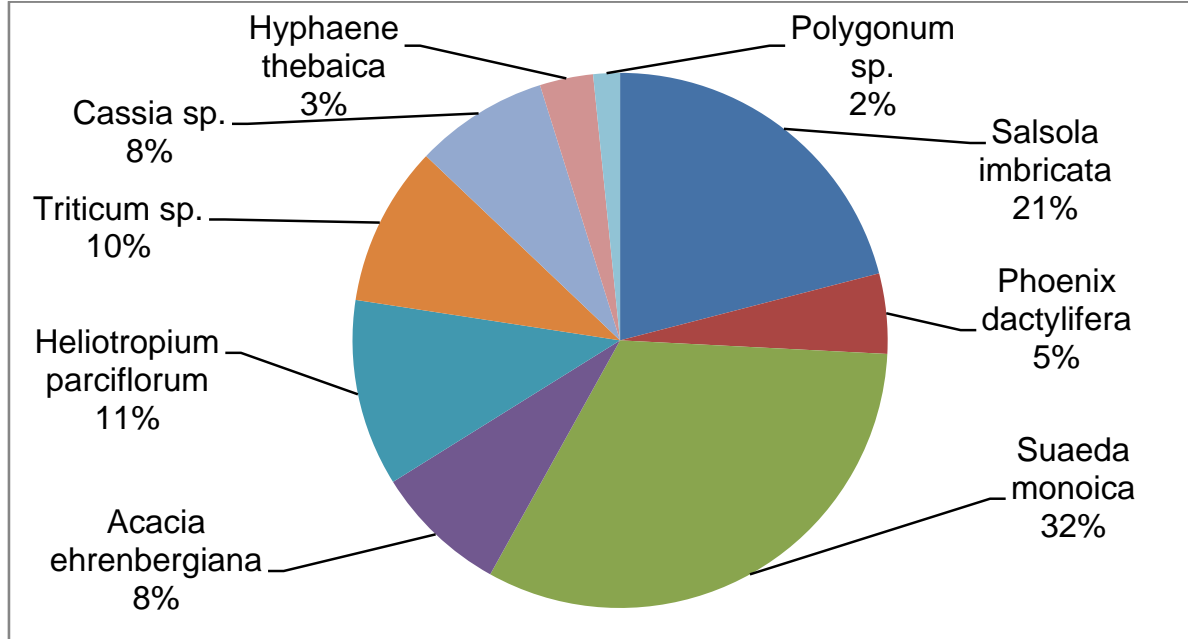

Figure 6. Proportions of different plant species identified form Um Hilal pollen sample.

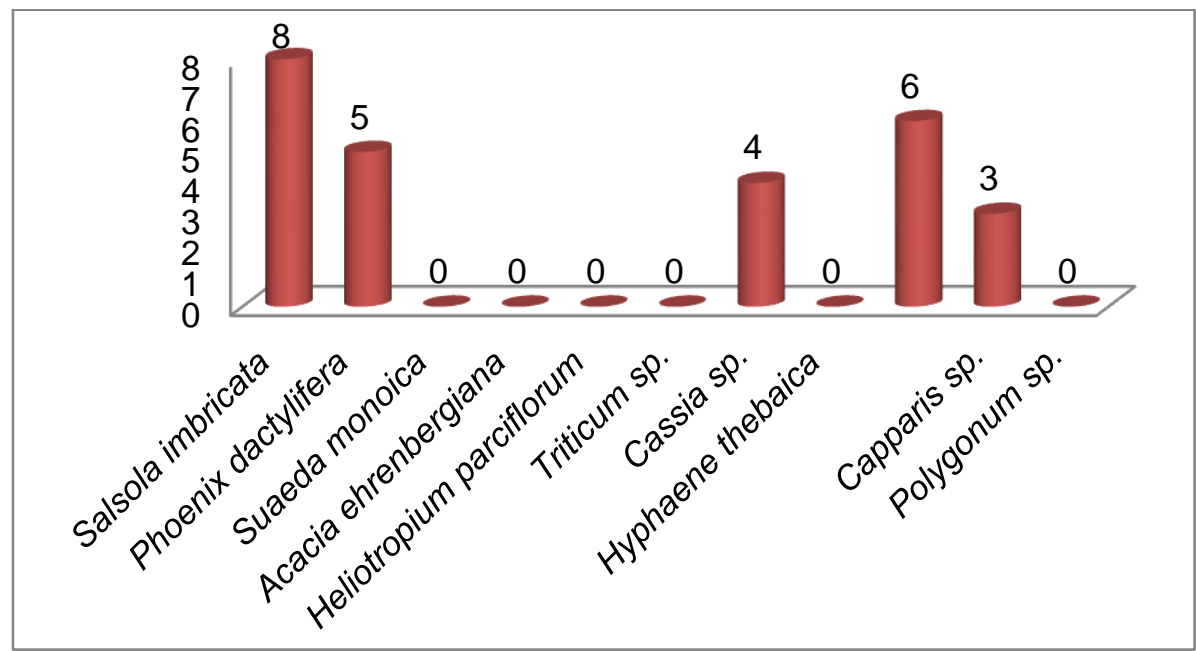

Figure 7. Proportions of different plant species identified form El Hamra pollen sample. 


\section{DISCUSSION}

The pollen grains analysis of the samples collected from the vegetation mounds of Um Hilal and El-Hamra sites provided direct and good evidence about some of the composition of the flora of this areas during the late Christian and early Islamic periods in El-Ga'ab depression. Diversity in the species identified from the pollen grains samples in the studied areas also indicates suitable habitats for vegetation growth in the past. Different colors and size of the collected coprolites samples indicate the potentiality of the vegetation mounds to preserve them in good conditions for a long time. The moist environment inside the vegetation mounds in Um Hilal and El-Hamra is probably the main reason behind the good preservation of both coprolites, pollens and other archaeological materials. This observation conforms with the results obtained by Madani et al. (2018). Concerning pollen preservation, This result is in agreement with the observations of Florenzano et al. (2018) who reported about the good quantity and quality of pollen obtained in their study on Sai Island compared to poor pollen samples obtained by Florenzano et al. (2016) in the desert in northern Sudan . Most of the pollen grains were identified as a Suaeda monoica (Suaeda) and Salsola imbricata (Ikhreet). According to Woldewahid et al. (2007) the Suaeda monoica plant community is identifiable in the coastal plain of Sudan and along the Arabian Red Sea coast, which gives clear evidence that the El-Ga'ab area provided the same conditions for those plant communities to grow. Both plant species are still dominant in other law elevated areas of less dry sand dunes grow in Um Hilal and El-Hamra. Polygonum sp. (Timsahya) in northern Sudan is distributed mainly on the Nile banks. The record of this pollen grain in Um Hilal area is an indication of moist habitat. A comparatively large number of tree pollen grain sample is recorded for Acacia ehrenbergiana Hayne which is still considered as a dominant plant species. The presence of the pollen grains of wheat (Triticum sp.) and of the commont weed in the northern Sudan agricultural schemes (Heliotropium parciflorum (Mart.) Gürke) is an evidence for the presence of agricultural activities in the past.

\section{CONCLUSION}

This research concluded that the vegetation mounds are suitable sites for preserving plant remains and animal coprolites. Studying plants and animals remains in different strata of these mounds will provide information about the past land use in which parts of the natural environment were modified into arable fields and pastures. Vegetation mounds could also explain the rate of sand erosion and land degradation processes in the desert. Most of the pollen grains were identified as a Suaeda monoica (Suaeda) and Salsola imbricata (Ikhreet). Which are salt-tolerant plants indicates the presence of saline habitats in El-Ga'ab depression. Up to date, both species are forming the dominant species of other law elevated areas of less dry sand dunes. the areas. The record of Polygonum sp. (Timsahya) in Um Hilal area is an indication of moist habitat. Record of a comparatively large number of tree pollen grain of Acacia ehrenbergiana indicates no change in the dominant tree species. The presence of the pollen grains of wheat (Triticum sp.) and (Heliotropium parciflorum) is an evidence for past agricultural activities. For reconstruction of the palaeoenvironment, further intensive investigations of the vegetation mounds formed in the desert of northern Sudan were recommended.

\section{ACKNOWLEDGEMENTS}

The authors gratefully acknowledge the valuable help and cooperation of the local people in El-Ga'ab areas, northern Sudan.

\section{REFERENCES}

Azzazy M.F. (2011). Morphological studies of the pollen grains of Wadi El-Natrun plants, WestNile Delta, Plant Systematics and Evolution, Egypt.

Babiker I.S. \& Mohamed A.A.M. (2017). Geology, Geomorphology and Hydrogeology of El Ga`ab Depression West of the Nile, North Sudan and their Implications to Early Population Settlements in the Area. Online International Interdisciplinary Research Journal, 7: 1-11.

Barakat H.N. (1995). Middle Holocene vegetation and human impact in central Sudan: charcoal from the Neolithic site at Kadero. Vegetation History and Archaeobotany, 4: 101-108.

El Ghazali G.E.B. (1993). A study on the pollen flora of Sudan. Review of Palaeobotany and Palynology, 76: 99-345.

Erdtman G. (1934). Upper die verwendung von Essigsaureanhydrid bei pollenuntersuchungen. Svensk Botanisk Tidskrift, 28(2): $354-$ 358.

Erdtman G. (1960). The acetolysis method. Svensk Botanisk Tidskrift, 54(4): 561-564.

Faegri K. \& Iversen J. (1975). Textbook of pollen analysis. Copenhagen.

Florenzano A. Mercuri A.M., Altunoz M. \& Garcea E.A.A. (2016). Palynological evidence of cultural and environmental connections in Sudanese Nubia during the Early and Middle Holocene. Quaternary International, 412: 65-80.

Florenzano A., Mercuri A.M., Fornaciari A. \& Garcea E.A.A. (2018). Plants, water and humans: pollen analysis from Holocene 
archaeological sites on Sai Island, northern Sudan. Palynology, 43: 22-33.

Gosling W.D., Mayle F.E., Killeen T.J., Siles M., Sanchez L. \& Boreham S. (2003). A simple and effective methodology for sampling modern pollen rain in tropical environments. Holocene, 13: 613-618.

Lezine A.M., Zheng W., Braconnot P. \& Krinner G. (2011). Late Holocene plant and climate evolution at Lake Yoa, northern Chad: pollen data and climate simulations. Climate of the Past, 7: 1351-1362.

Lopez Saez J.A. \& Garcia L.G. (2003). Pollen analysis from Early and Middle Holocene archaeological sites in the Blue Nile area, Central Sudan. Complutum, 14: 397-400.

Madani I., Pokorny P., Tahir Y.F., Hamdeen H.M. \& Pokorna A. (2018). Vegetation Mounds in El-Ga'ab Depression (Sudan): Their Significance in Archaeology and Archeaobotany. In: Kabacinski J. (Ed.) Desert and the Nile: Brehistory of the Nile Basin and the Sahara, Poznan Archaeological Musuem. pp. 473-483.

Madani I., Tahir Y.F., Hamdeen H.M., Pokorna A. \& Pokorny P. (2015). Vegetation ecology and Taxonomy of El Ga'ab area, North-western Sudan. European Academic Research, 3: 2927-2943.

Mercuri A.M. (2008). Human influence, plant landscape, evolution and climate inferences from the archaeobotanical records of the Wadi Teshuinat area (Libyan Sahara). Journal of Arid Environments, 72: 1950-1967.

Mercuri A.M., Sadori L. \& Uzquiano Ollero P. (2011). Mediterranean and northAfrican cultural adaptations to mid-Holocene environmental and climatic change. Holocene, 21: 189-206.

Tahir F.Y. (2012). A Holocene Paleolake in El-Ga'ab depression Western desert, Northern Sudan. Sahara, 23: 99-122.

Watrin J., Lézine A.-M., Hély C. \& Contributors (2009). Plant migration and ecosystems at the time of the "green Sahara". $C R$ Geoscience, 341: 656-670.

Wickens G.E. (1982). Palaeobotanical Speculations and Quaternary Environments in the Sudan. In: Williamson M.A.J. \& Adamson D.A. (Eds.) A Land between Two Niles: Quaternary geology and biology of the Central Sudan. Rotterdam - Balkema, pp. 23-50.

Woldewahida G., van der Werfb, Sykorac W.K., Abated T., Mostofae B. \& van Huisa A. (2007). Description of plant communities on the Red Sea coastal plain of Sudan. Journal of Arid Environments, 68: 113-131. 